\title{
Foreign Direct Investment in Global Cities and Co-Ethnic Clusters: Characteristics, Profitability, and Survival
}

\author{
Dwarka Chakravarty
}

Ph.D. awarded by Ivey Business School, Canada (August 2018)

\section{BIG Question:}

How does subsidiary location within global cities and co-ethnic clusters impact the characteristics, profitability, and survival of foreign direct investment?

\section{Introduction}

The traditional approach of using entire countries as location units of analysis in IB research obscures micro-level drivers which better explain FDI choices and consequences (Beugelsdijk \& Mudambi, 2013). Recognizing this, of late there has been greater focus on using finer-grained, sub-national units such as states, metropolitan statistical areas (MSAs), cities, and clusters.

This article is motivated by two important, yet understudied phenomena regarding sub-national FDI. The first is the attraction of FDI towards "global cities" (GCs) such as New York, Los Angeles, and Toronto. Commencing in the 1980s, the internationalization of production and services and consequent increase in economic and geographic complexity accelerated the rise of certain cities as command and control points for MNEs. Cities such as London, New York, Tokyo, and Hong Kong which provided an advanced level of professional services and connectivity for managing these global production networks became highly influential in the world economy. Sassen (1991) defined such cities as global cities. Based on her work, a widely used list of world cities was developed (Beaverstock, Smith, \& Taylor, 1999) which includes 23 in North America (see Table 1). GCs provide MNEs with a range of economic, institutional, and ecosystem advantages including connections to local and global markets, cosmopolitan environments, and advanced services (Goerzen, Asmussen, \& Nielsen, 2013). Offering much more than new markets to MNEs, they serve as strategic points for access to and exchange of knowledge, technology, capital, and skilled human resources (Wagner, 2008).

The second motivating phenomenon is the tendency of MNEs to agglomerate in close proximity to their home country and industry peers in clusters, that are not limited by administrative boundaries of cities and metro areas. Japanese firms often seek out US locations where other Japanese firms are located; as do English, German, and Korean firms (Crozet, Mayer, \& Mucchielli, 2004). Within such co-ethnic concentrations, we often find clusters of subsidiaries belonging to the same in- 
dustry sector. I denote these as "co-ethnic and co-industry" (CECI) clusters. Subsidiary location in co-ethnic (CE) and co-ethnic and co-industry (CECI) clusters can be advantageous for several reasons. Co-ethnicity provides a basis for trust through a common cultural, linguistic, and social ground, enabling economic interaction and information sharing. This is particularly valuable when tacit and sensitive knowledge is involved (Chang \& Park, 2005). CECI clusters can promote positive knowledge spillovers because firms from the same home country and industry are more likely to have similar technology and management practices. CECI clusters can also provide resource, efficiency, and scale benefits via access to specialized labor and suppliers, reduced transportation costs, and sharing of equipment and infrastructure (Kim, Delios, \& Xu, 2010; Marshall, 1920).

\section{Research Rationale}

Substantial FDI is directed towards GCs, their metropolitan areas (metros), and co-ethnic clusters. For instance, from 19902014, nearly 50\% of Japanese subsidiaries in North America were established in 23 GCs and their metros out of a possible 415 such North American MSAs (See Figure 1). Across all locations (GCs, metros, others), close to $65 \%$ of all subsidiaries were established in co-ethnic clusters and over $40 \%$ were established in co-ethnic and co-industry (CECI) clusters. Despite its pervasiveness, research regarding FDI in GCs, metros, and co-ethnic clusters remains underexplored and lacks comprehensive and precise examination using large longitudinal samples, multi-level methods, and geo-spatial analysis that bridges IB and economic geography. Hence, we know very little about how these sub-national locations affect investment characteristics, and if they provide performance benefits that overcome potentially adverse effects of cost, competition, and negative knowledge spillovers.

This article focuses on the above gaps by addressing the following research questions. First, how do subsidiary and MNE characteristics differ between GCs, metros, and other locations? Second, how does subsidiary performance (profitability and survival) differ between these locations? Third, how do co-ethnic and CECI clusters impact subsidiary performance?
This article will help MNE managers better understand the risks vs. rewards of specific location choices in North America and actions they can take to improve their odds of success.

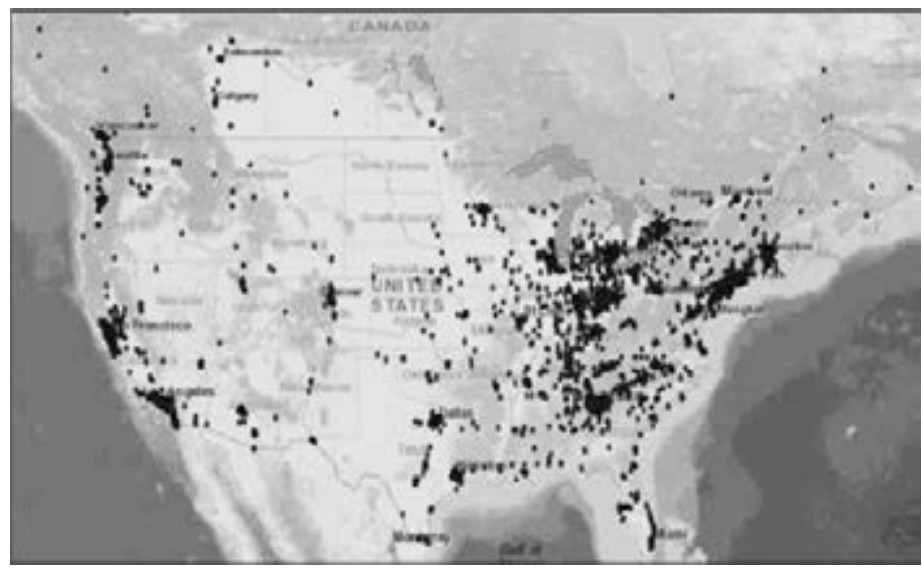

Figure 1. Japanese FDI in North America (1990-2013). Source: Toyo Keizai, 2014.

\section{Research Design}

A sample of Japanese subsidiaries in North America over the time period 1990-2013 from the Toyo Keizai 2014 database was used. The sample comprises 25,347 subsidiary-years (2,863 unique subsidiaries of 1,605 MNEs). 23 North American GCs were identified from Beaverstock et al.'s (1999) widely used list, which is consistent with Sassen's (1991) GC concept, and whose listing year is close to the middle of the data range.

To obtain a precise measure for subsidiary location (i.e., GC/ metro/other), subsidiary street addresses were converted to the corresponding latitude and longitude using Google Maps. Then ArcGIS 10.5 software was used to plot each subsidiary co-ordinate (latitude, longitude) as a point on a geospatial map of North America. US and Canada census map layers were added to delineate GC limits, GC metro areas, and other locations (outside of GCs and metros) To illustrate, Figure $2 \mathrm{a}$ (on the left) depicts subsidiaries (black dots) in the GC of Chicago (cross hatched), and its surrounding metro area (black outlined).

Clusters were determined (at a 95\% confidence level) based on geo-spatial location, proximity, and density analysis using

Table 1: Global Cities in North America

\begin{tabular}{|l|l|l|l|l|}
\hline Canada & USA & \multicolumn{4}{|l|}{} \\
\hline Calgary & Atlanta & Columbus & Los Angeles & Richmond \\
\hline Montreal & Boston & Dallas & Miami & San Francisco \\
\hline Toronto & Baltimore & Detroit & Minneapolis & Seattle \\
\hline Vancouver & Chicago & Houston & New York & Washington DC \\
\hline & Cleveland & Kansas City & Philadelphia & \\
\hline
\end{tabular}




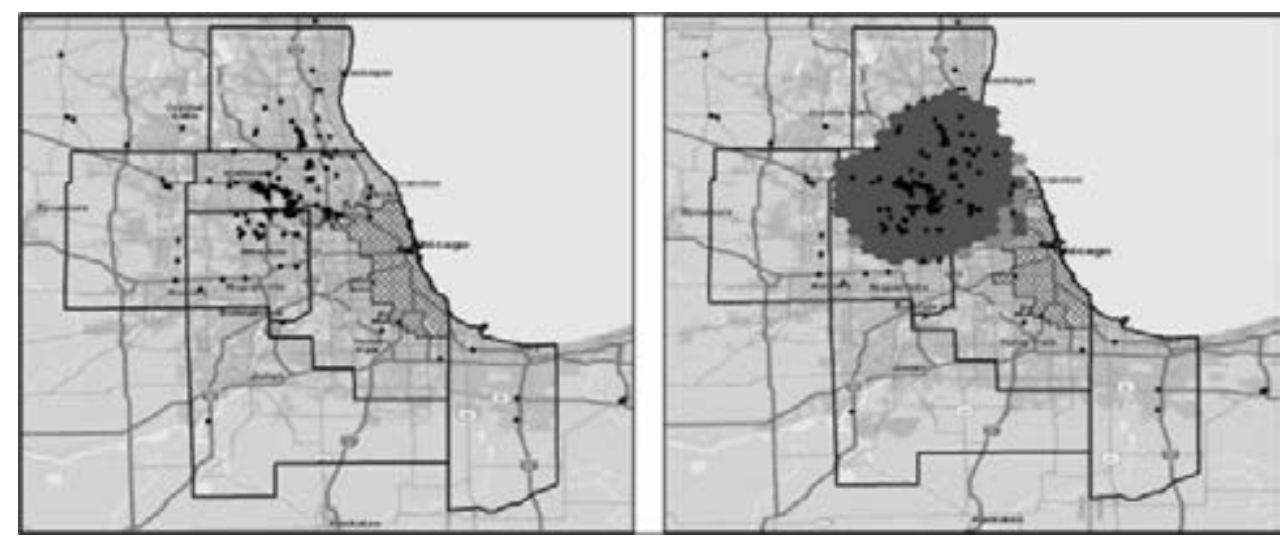

Figures $2 a$ and $2 b$. Japanese Subsidiaries and Co-Ethnic Clusters in Chicago and Its Metro Area

the Optimized HotSpot tool in ArcGIS 10.5. This tool identifies statistically significant spatial clusters based on the number of neighbors for each subsidiary within a given geographical boundary. Consistent with prior research (e.g., Stallkamp, Pinkham, Schotter, \& Buchel, 2018), a 15-kilometre boundary radius was used. To identify co-ethnic clusters, the analysis was conducted for subsidiaries across all industry sectors. To identify co-ethnic and co-industry (CECI) clusters the analysis was done for groups of subsidiaries within each of the following industry sectors - automotive, electronics, machinery, financial services, real estate, and transportation. Figure 3a (on the left) shows a cluster of Japanese automotive subsidiaries in the Detroit-Windsor area and Figure $3 \mathrm{~b}$ (on the right) shows a cluster of Japanese chemicals subsidiaries in the Los Angeles area.

For regressions, a multi-level longitudinal model was applied wherein subsidiaries are nested within firms and repeated measures over time are nested within subsidiaries. Ordinal logistic regression and a parametric hazard model were used for profitability and survival analysis respectively, with both models accounting for non-proportional odds.

\section{Findings}

\section{Characteristics}

FDI in GCs substantially differs from metros and other locations across subsidiary and MNE characteristics. A GC subsidiary is likely to be a smaller size, wholly owned services unit, with a relatively high percentage of expatriate employees; a metro subsidiary is likely to be an intermediate size wholesale operation, with a lower percentage of expatriate employees; while a subsidiary operating outside of these areas is likely a large manufacturing unit with the lowest percentage of expatriates. See Table 2. MNEs operating across all three areas have the highest levels of tangible assets and advertising intensities, however MNEs operating in metros and other locations have intermediate levels of tangible assets but the highest $R \& D$ intensities, and MNEs operating outside of GCs and metros have the lowest levels of tangible and intangible assets. See Tables 2 and 3.

\section{Profitability}

Subsidiaries in GCs and metros are twice as likely to be profitable relative to their counterparts in other locations. These outcomes are strengthened for services subsidiaries in GCs which are 2.5 times more likely to be profitable than peers in other locations; and manufacturing subsidiaries in metros which have 2.5 times and 1.7 times greater profitability odds than peers in other locations and GCs respectively. Both co-ethnic (CE) and co-ethnic and co-industry (CECI) clusters further boost subsidiary profitability. CE cluster membership improves GC subsidiary profitability odds by 1.7 times, and GC and metro subsidiaries in CECI clusters are 2.5 to 3 times more likely to be profitable.
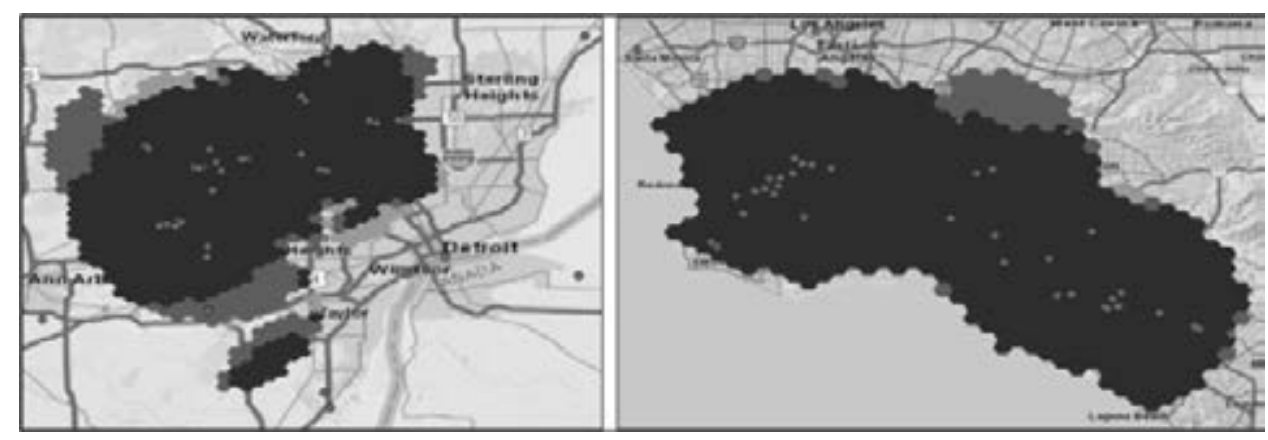

Figures $3 a$ and $3 b$. Co-Ethnic and Co-Industry Clusters - Detroit (Automotive) and LA (Chemicals)

\section{Survival}

Subsidiaries in GCs and metros are less likely to survive (face about 1.4 times higher exit risk) relative to their peers in other locations. Services subsidiaries in GCs and manufacturing subsidiaries in metros face 2 times and 1.4 times higher exit risk relative to their industry peers in other locations. While exit risk does not significantly differ for subsidiaries in CE clusters, CECI clusters reduce exit risk by 5 times in locations outside of GCs and metros. 
Table 4 provides a comparison of subsidiary profitability and survival findings. These suggest that while average subsidiary profitability in GCs and metros is better than in other loca-

Table 2: (Selected) Subsidiary Characteristics

\begin{tabular}{|l|l|l|l|}
\hline Subsidiary Characteristic & GCs & Metros & Other \\
\hline Average Employees & 117 & 145 & 253 \\
\hline Average Expatriates & 11.6 & 8.5 & 6.3 \\
\hline Expatriates \% (of Employees) & 14.3 & 8.7 & 4.7 \\
\hline Wholly Owned \% & 81.2 & 78.4 & 64.0 \\
\hline Services \% & 47.7 & 34.9 & 17.4 \\
\hline Manufacturing \% & 11.1 & 28.8 & 60.1 \\
\hline Wholesale \% & 26.2 & 59.2 & 14.6 \\
\hline
\end{tabular}

Table 3: (Selected) MNE Characteristics

\begin{tabular}{|l|l|l|l|}
\hline $\begin{array}{l}\text { MNE Characteristic } \\
\text { (Averages) }\end{array}$ & $\begin{array}{l}\text { MNEs with sub- } \\
\text { sidiaries in GCs } \\
\text { \& metros \& } \\
\text { other locations }\end{array}$ & $\begin{array}{l}\text { MNEs with sub- } \\
\text { sidiaries only in } \\
\text { metros \& other } \\
\text { locations }\end{array}$ & $\begin{array}{l}\text { MNEs with } \\
\text { subsidiaries } \\
\text { only in other } \\
\text { locations }\end{array}$ \\
\hline Employees & 22,775 & 8,732 & 2,535 \\
\hline Revenue ('000 USD) & $1,506,983$ & 287,843 & 69,956 \\
\hline Assets ('000 USD) & $1,345,532$ & 286,862 & 64,404 \\
\hline International Experience (years) & 687 & 262 & 95 \\
\hline R\&D Intensity \% & 2.3 & 3.2 & 1.7 \\
\hline Advertising Intensity \% & 1.6 & 1.4 & 1.1 \\
\hline
\end{tabular}

Table 4: Comparison of Profitability and Survival Findings by Location and Cluster

\begin{tabular}{|l|l|l|}
\hline Location & Profitability & Survival \\
\hline Global City & $\begin{array}{l}\text { 2 times greater odds of profitability vs. } \\
\text { other locations; and 2.5 times for Services } \\
\text { subsidiaries; differences with metro peers } \\
\text { not significant. }\end{array}$ & $\begin{array}{l}\text { 1.5 times exit risk vs. other locations; } \\
\text { and 2 times for Services subsidiaries; } \\
\text { differences with metro peers not } \\
\text { significant. }\end{array}$ \\
\hline Metro & $\begin{array}{l}\text { 2 times greater odds of profitability vs. other } \\
\text { Locations; Mfg. subsidiaries 2.5 and 1.7 } \\
\text { times more likely to be profitable relative to } \\
\text { peers in other locations and GCs. }\end{array}$ & $\begin{array}{l}1.3 \text { times greater exit risk vs. other } \\
\text { locations; 1.4 times for Mfg. } \\
\text { subsidiaries; differences with GC } \\
\text { peers not significant. }\end{array}$ \\
\hline Other & As above & As above \\
\hline $\begin{array}{l}\text { Co-Ethnic } \\
\text { Cluster }\end{array}$ & $\begin{array}{l}1.7 \text { times greater odds of profitability } \\
\text { relative to un-clustered peers in metros; } \\
\text { insignificant in GCs and other locations. }\end{array}$ & $\begin{array}{l}\text { No significant differences in exit risk } \\
\text { relative to un-clustered peers. }\end{array}$ \\
\hline $\begin{array}{l}\text { Co-Ethnic, } \\
\text { Co-Industry } \\
\text { Cluster }\end{array}$ & $\begin{array}{l}3 \text { times and 2.5 times more likely to be } \\
\text { profitable relative to un-clustered peers in } \\
\text { GCs and metros respectively; insignificant in } \\
\text { other locations. }\end{array}$ & $\begin{array}{l}\text { Exit risk 5 times lower than un- } \\
\text { clustered peers in other locations; } \\
\text { insignificant in GCs and metros. }\end{array}$ \\
\hline
\end{tabular}




\section{Managerial Implications}

MNEs seeking access to markets and/or knowledge should establish services subsidiaries in GCs and manufacturing subsidiaries in metros

Subsidiaries established for business development and knowledge seeking reasons will benefit from customer proximity and innovation ecosystems. The downtown Houston branch of Japan's largest bank- Mitsubishi UFJ, is located near the offices of its main customers-Japanese and US energy companies. The Dutch MNE Philips' North America health technology research center is located in metro Boston. To improve the likelihood of profitability for market/knowledge seeking subsidiaries, I recommend locating services subsidiaries in GCs and manufacturing in metros. Knowledge seeking subsidiaries may further benefit from metro locations within diverse CE clusters.

In GCs and metros, average profitability is better, but greater corporate scrutiny and higher expectations may lower survival rates for the weaker to moderate performers. Hence, subsidiary managers must make the case for greater corporate-level tolerance while the subsidiary establishes itself and overcomes challenges of higher costs and competition.

\section{MNEs seeking efficiency and/or resources should establish subsidiaries outside GCs/metros}

Long-term survival may be a more relevant performance measure for efficiency/resource seeking subsidiaries. Such operations are generally capital intensive, requiring stability and sustained cost advantages to generate returns. Large-scale manufacturing and distribution activities will benefit from availability of lower cost factors of production. Toyota's largest automobile plant is built on 1,300 acres in Georgetown, Kentucky. The Belgian steel-maker Arcelor-Mittal's rural Indiana plant is located near the Morse reservoir, since steel production requires copious amounts of water. CECI clusters may further improve survival prospects in such locations.

Across GCs, metros, and other locations, MNEs should seek to establish subsidiaries within co-ethnic (CE) and co-ethnic and co-industry (CECI) clusters

$\mathrm{CE}$ and CECI clusters improve subsidiary profitability in GCs and metros, and CECI clusters enhance survival odds in other locations. Our analysis suggests that a conservative heuristic for (CE or CECI) cluster membership is 10 neighbors within 10 miles.

\section{References}

Beaverstock, J. V., Smith, R. G., \& Taylor, P. J. 1999. A roster of world cities. Cities, 16(6): 445-458.

Beugelsdijk, S., \& Mudambi, R. 2013. MNEs as border-crossing multi-location enterprises: The role of discontinuities in geographic space. Journal of International Business Studies, 44(5): 413-426.

Chacar, A., \& Vissa, B. 2005. Are emerging economies less efficient? Performance persistence and the impact of business group affiliation. Strategic Management Journal, 26(10): 933-946.

Chang, S.J., \& Park, S. 2005. Types of firms generating network externalities and MNCs' co-location decisions. Strategic Management Journal, 26(7): 595-615.

Crozet, M., Mayer, T., \& Mucchielli, J.L. 2004. How do firms agglomerate? A study of FDI in France. Regional Science and Urban Economics, 34(1): 27-54.

Goerzen, A., Asmussen, C. G., \& Nielsen, B. B. 2013. Global cities and multinational enterprise location strategy. Journal of International Business Studies, 44(5): 427-450.

Kim, T.Y., Delios, A. \& Xu, D. 2010. Organizational geography, experiential learning and subsidiary exit: Japanese foreign expansions in China, 1979-2001. Journal of Economic Geography, 10(4): 579-597.

Marshall, A. 1920. Principles of economics. London: Macmillan.

Sassen, S. 1991. The global city: New York, London, Tokyo. Princeton, NJ: Princeton University Press.

Stallkamp, M., Pinkham, B. C., Schotter, A. P., \& Buchel, O. 2018. Core or periphery? The effects of country-of-origin agglomerations on the within-country expansion of MNEs. Journal of International Business Studies, 49(8): 942-966.

Wagner, D. 2008. Learning from Global Cities, MIT Sloan Management Review, 49(4): 10-11.

Dwarka Chakravarty (dchakravarty@sdsu.edu) is an Assistant Professor of Strategic Management at the Fowler College of Business, San Diego State University. His research interests include global cities, regional strategy, and emerging market multinationals. Prior to his Ph.D., he received an MBA from the Indian Institute of Management, Bangalore; and worked with KPMG Consulting in the UK; and with Microsoft in India and the Philippines. 